\title{
TEORI FUNGSIONALISME DILIHAT DARI SUDUT PANDANG ANTROPOLOGI
}

\author{
Mata Kuliah Antropologi Hukum \\ NADILA ADHA \\ BP : 2110003600160 \\ Kelas : $1 \mathrm{~h} 8$ \\ Dosen : DR. Laurensius Ariman S
}

A. PENDAHULUAN

Kebudayaan merupakan hasil cipta, rasa, dan karsa manusia yang diperoleh melalui belajar. Kebudayaan juga bagian yang tidak terpisahkan dari diri manusia. Kehadiran kebudayaan itu sendiri tidak terlepas dari manusia. Di dalam dunia ini kebudayaan terkait dengan manusi yang merupakan sebuah sistem. Begitulah manusia selalu berada dalam kehidupan yang bercorak fungsionalitas antarsubsistemnya. Agama, ekonomi, seni, dan teknologi, dan sebagaimana memiliki kaitan fungsionalisme dengan kehidupan umat manusia. Pada abad ke 18, seiring dengan perkembangan aliran-aliran baru di dalam kancah antropologi budaya. Teori fungsionalisme berkembang di Inggris kemudian di Amerika. Malinowski merupakan tokoh yang berperan penting dalam ilmu antropologi. Kegemaran yang dimilikinya yaitu tertarik pada psikologi, menjadikan ia melakukan penelitian di suatu wilayah yang terletak di Kepulauan Trobriand.

Berdasarkan pemaparan di atas, pemakalah akan menguraikan pokok bahasan ini berdasarkan pertanyaan di bawah ini:

1. konsep fungsionalisme?

2. Siapakah tokoh yang berperan dalam ilmu antropologi yang mengkaji mengenai teori fungsionalisme?

3. Bagaimanakah konsep yang dipakai Malinowski dalam penelitiannya?

4. Bagaimana Kaitan antara fungsionalisme dengan strukturalisme?

5. Kelemahan teori fungsionalisme?

B. PEMBAHASAN

1. Konsep fungsionalisme

Fungsi pada dasarnya ada dua bentuk sudut pandang yaitu: Fungsi dalam masyarakat yang merupakan satu kesatuan yang integral. Masyarakat adalah suatu sistem yang secara keseluruhan terdiri dari bagian-bagian yang saling tergantung (http://www.scribd.com/doc/23711839/teori-fungsional). Kemudian dari sisi fungsi 
kebudayaan adalah kemampuan kebudayaan itu untuk memenuhi kebutuhan individu anggotanya dalam konteks batasan yang dibentuk oleh kebudayaan itu. Asumsi dasar dari fungsionalisme adalah seluruh elemen kebudayaan untuk memenuhi kebutuhan individu.

Asumsi dasar fungsionalisme merupakan seluruh elemen suatu suku, bangsa, masyarakat berfungsi untuk memenuhi kebutuhan kelangsungan kebudayaan dari setiap anggota-anggotanya. Fungsional merupakan kemampuan suatu kebudayaan yang berfungsi untuk memenuhi kebutuhan-kebutuhan individu dalam masyarakat baik itu kebutuhan primer maupun kebutuhan skunder. Fungsional membentuk integral kebudayaan atau sebuah lingkaran kebudayaan, satu elemen kebudayaan memenuhi beberapa unsur kebudayaan dalam masyarakat, jika salah satu elemen terganggu maka elemen yang lain juga akan terganggu karena fungsionalisme membentuk sebuah lingkaran kebudayaan.

2. Biografi Bronislaw Malinowski

Aliran fungsionalisme structural berkembang di Inggris, dan kemudian di Amerika pada abad ke 18. Peranannya yang sangat berpengaruh besar adalah pada temuan konseptualnya mengenai peranan kebudayaan di dalam kehidupan manusia bagi yang primitive maupun yang modern (Syam, 2006: 30). Dalam teori antropologi dalam mengembangkan teori-teorinya terdapat seorang tokoh yang sangat penting dalam sejarah antropologi yaitu Bronislaw Malinowski (1884-1942). la dilahirkan di Cracow, Polandia sebagai putera keluarga bangsawan Polandia. Ayahnya seorang guru besar dalam IImu Sastra Slavik. Pada tahun 1908 ia lulus Fakultas IImu Pasti dan Alam dari universitas di Cracow. Selama studinya ia sudah tertarik kepada buku yang berisikan foklor dan dongengdongeng tentang rakyat. Hal demikian mengakibatkan ia mempelajari psikologi. Dalam foklor tersebut ia banyak membaca mengenai ilmu ghaib yang pada akhirnya merambah dunia etnologi. Pada saat ia melanjutkan ke perguruan Tinggi, tepat tahun 1916 mendapat gelar doktor dengan memberikan dua buah judul karangan buku. Demikian dilakukan sebagai ganti disertasi, yaitu The Family Among the Australian Aborigines dan The Native of Mailu. Kedua karangan tersebut dilakukan dengan cara membaca, artinya tidak turun ke lapangan secara langsung. Berbagai macam buku dibaca waktu itu, sehingga ia tertarik untuk mengadakan penelitian secara langsung di pulau itu. (Baal, 1988: 49)

Melalui bantuan seseorang yang bernama Seligman, pada tahun 1914 ia dapat pergi ke kepulauan Trobiand untuk penelitian di bagian utara Kepulauan Masim sebelah Tenggara Papua Nugini. Pada saat itu pula Perang Dunia pecah antara Inggris dan Australia berlawanan. Akan tetapi berkat rekomendasi Seligman Malinowski diperbolehkan untuk tinggal di Kepulauan Trobriand untuk mengobservasi dan meneliti orang Trobriand selama lebih dari dua tahun. Setelah perang usai pada tahun 1918, ia pergi ke Inggris karena mendapat pekerjaan sebagai asisten ahli di London School of Economics. Akibat 
terserang penyakit paru-paru, maka baru dalam tahun 1921 ia dapat mulai melakukan penulisan buku-buku hasil penelitiannya di Papua Nugini. Buku yang pertama yang telah banyak menarik perhatian dunia ilmu etnologi dan antropologi masa itu adalah Argonauts of the Western Pacific tahun 1922. Malinowski naik pangkat menjadi lektor pada tahun 1924 dan pada tahun 1926 ia menerbitkan buku keduanya mengenai Trobriand yaitu Crime and Custom in Savage Society. Setahun kemudian ia di angkat menjadi guru besar penuh dalam ilmu antopologi. Setelah itu terbit lagi dua buah buku hasil penelitiannya di Trobriand yaitu The Sexual Life Of the Savages ( 1929) dan kedua dalam jilid tebal Coral Gaerdens and Theirs Magic (1935).

Sebenarnya ia sudah mengalihkan perhatianya kepada hal-hal lain pada waktu sebelumya. Berkaitan dengan perhatiannya terhadap antropologi praktis dan terapan, ia diminta menjadi konsultan Departemen Pemerintahan Kolonial Inggris. Dalam kedudukannya itu ia pernah mengunjungi Afrika Selatan dan Afrika Timur pada tahun 1934. la juga banyak diundang untuk memberi ceramah di berbagai universitas di Eropa dan di Amerika dalam dasawarsa antara tahun 1926-1936. Pada tahun 1938 ia sekali pergi ke Amerika Serikat dan akhirnya menetap di negara itu dan pada saat setelah Perag Dunia II pecah tahun 1939. Ketika ia diundang oleh guru besar tamu di Universitas Yale. Pada saat itu pula tertarik lagi pada kesukaanya ilmu psikologi. Hal demikian disebabkan di Universitas itu ada ahli-ahli psikologi behaviorisme seperti N.E Miller dan J. Dollard yang mengembangkan teori-teori baru tentang proses belajar sebagai hasil penelitian-penelitian mereka dengan binatang-binatang percobaan di laboratorium.

Keadaan seperti itu mengakibatkan ia mulai mengembangkan suatu teori baru untuk menganalisa fungsi dari kebudayaan manusia yang disebut suatu teori fungsional tentang kebudayaan atau a functional thory of culture. la kemudian memutuskan untuk menetap di Amerika Serikat ketika ia ditawari menjadi guru besar antropologi di Universitas itu pada tahun 1942. Sangat disayangkan, pada tahun itu juga ia meninggal dunia. Buku teori baru yang ditulisnya tidak dapat dialaminya lagi. Salah seorang muridnya $\mathrm{H}$. Chairns meredaksi dan menerbitkan buku itu secara anumerta dua tahun kemudian.

3. Teori fungsionalisme malinowski

Berdasarkan biografi Malinowski di atas, maka konsep dari pemikiran teori yang dikemukakan dari penelitiannya dapat di bagi menjadi beberapa konsep yaitu (Koentjaraningrat, 2007:164-172):

a. Etnografi Berintegrasi Secara Fungsional

Argonauts of the Western Pacific merupakan judul karangan pertama yang ditulis dalam penelitian di Kepulauan Trobriand sebelah Tenggara Papua Nugini pada tahun 1922. Di sana banyak yang menarik perhatiannya, tidak hanya para ahli antropologi dan pakar 
sosiologi. Tetapi juga kalangan awam. Pokok pelukisannya adalah suatu sistem perdagangan antara penduduk Kepulauan Trobriand, Kepulauan Amphlett, Kepulauan D' entrecastreaux, Pulau St. Agnau, Kepulauan Laughlan, Kepulauan Woodlark, yang semuanya terletak di sebelah Timur Pucuk ekor Papua Nugini Tenggara. Dengan hanya perahu-perahu kecil yang bercadik dan menggunakan awak kapal yang bermuatan 15 orang, masyarakat Trobriand dan penduduk lain berani menyeberangi lautan terbuka untuk berlayar dari satu pulau ke pulau lainnya bermil-mil jauhnya. Perdagangan dilakukan dengan cara sistem barter berupa berbagai macam bahan makanan, barang kerajinan, alatalat perikanan, perkebunan dan alat-alat rumah tangga. Namun, ada hal yang lain lagi yaitu pertukaran dua macam perhiasan yang dianggap mempunyai nilai yang tinggi yaitu kalungkalung kerang (sulava) yang beredar ke satu arah mengikuti arah jarum jam dan gelanggelang kerang(mwali) yang beredar kea rah berlawanan. Sistem perdagangan disebut sistem kula.

Ada hal yang unik dari etnografi Malinowski yang belum pernah dilakukan oleh pengarang lainnya adalah cara Malinowski menggambarkan keterkaitan hubungan antara sistem kula dengan lingkungan alam sekitar pulau-pulau serta berbagai macam unsur kebudayaan dan masyarakat penduduknya. Gambaran itu meliputi ciri-ciri fisik dari lingkungan alam tiap pula, keindahan laut kerangnya, aneka warna floranya, pola-pola pemukiman komunitas serta kebun-kebunya. Bahan-bahan tersebut diuraikan sehingga seluruh aktivitas kehidupan di depan mata kita sebagai suatu sistem sosial berintegrasi secara fungsional. Pemikiran Malinowki mengenai syarat-syarat metode etnografi secara fungsional yang dikembangkanknya tentang metode penelitian lapangan mengenai kebudayaan Trobriand. Hal ini menyebabkan bahwa konsep tentang fungsi sosial dari adat, tingkah laku manusia, dan pranata-pranata sosial menjadi lebih bagus. Dalam hal ia membedakan antara fungsi sosial dalam tiga abstraksi yaitu:

1) Mengenai pengaruh atau efeknya terhadap adat, tingkah laku manusia dan pranata sosial yang lain dalam masyarakat.

2) Pengaruh atau efeknya terhadap kebutuhan suatu adat atau pranata lain untuk mencapai maksudnya, seperti yang dikonsepsikan oleh warga masyarakat yang bersangkutan.

3) Terhadap kebutuhan muhktlak untuk berlangsungnya secara terintegrasi dari suatu sistem sosial yang tertentu.

b. Konsep- konsep Malinowski yang Lain

Persoalan yang dikemukakan oleh Malinowski juga menyangkut aktivitas pengendalian sosial atau hukum. Masalah yang dianalisa adalah sebagai berikut: 
1) Dalam masyarakat modern, tata tertib kemasyarakatan dijaga antara lain oleh suatu sistem pengendalian sosial yang bersifat memaksa, yaitu hukum. Untuk melaksanakannya hukum disokong oleh suatu sistem alat-alat kekuasaan yang diorganisasi oleh suatu negara.

2) Dalam masyarakat primitif alat-alat kekuasaan serupa itu kadang-kadang tidak ada.

c. Teori Fungsional Tentang Kebudayaan

Kesenagan Malinowski terhadap psikologi, dan mengunjungi Universitas Yale di Amerika Serikat. Ketika ia meneliti penduduk yang ada di Trobriand, secara tidak sengaja mengintroduksikan pandangan yang baru dalam ilmu antropologi. Reaksi tersebut malahan memberi dorongan untuk mengembangkan suatu teori tentang fungsi dari unsur-unsur kebudayaan manusia. Inti dari teori ini adalah pendirian bahwa segala aktivitas kebudayaan itu sebenarnya bermaksud memuaskan suatu rangkaian dari sejumlah kebutuhan naluri mahkluk manusia yang berhubungan dengan seluruh seluruh kehidupannya. Sebagai contoh mengenai dari salah satu unsur kebudayaan, misalnya terjadi karena mula-mula manusia ingin memuaskan kebutuhan nalurinya akan keindahan. Ilmu pengetahuan juga timbul karena kebutuhan naluri manusia untuk tahu. Dengan begitu Malinowski menganalisa banyak masalah dalam kehidupan masyarakat dan kebudayaan manusia.

d. Malinowski Tentang Perubahan Kebudayaan.

Pada saat karyanya mengenai berbagai aspek kehidupan masyarakat penduduk Kepulauan Trobriand muncul reaksi dari banyak kalangan antropologi adalah bahwa Malinowski tidak memperhatikan proses-proses perkembangan kebudayaan dalam pemikiran-pemikirannya. Dengan melukiskan suatu masyarakat dengan mengintegrasikan seluruh aspeknya menjadi satu. Pada masa akhir hidupnya ia berhasil menulis sebuah buku yang terbit anumerta berjudul The Dynamics of Culture Chang, An Inqury info Race Relation in Afrika pada tahun 1945. Dengan mengambil bahan dan contoh-contoh dari Afrika. Isi dalam buku itu mengajukan suatu metode untuk mencatat dan menganalisa sejarah dan proses-proses perubahan kebudayaan dalam suatu masyarakat yang hidup.

4. Kaitan antara fungsionalisme dengan strukturalisme

Fungsionalisme struktural adalah salah satu paham atau ajaran mengenai perspektif sosiologi yanng memandang masyarakat sebagai suatu sistem yang terdiri dari bagianbagian yang saling berhubungan satu sama lain dan bagian yang satu tidak akan berfungsi tanpa ada hubungan dengan bagian yang lain. Asumsi dasar dari teori fungsionalisme struktural ini bagaimana menciptakan suatu keseimbangan dalam suatu sistem dengan menjalankan fungsi masing-masing dari setiap elemen maupun unsur dalam sebuah 
sistem. Jadi, jelas bahwa kaitan antara strukturalisme dengan fungsionalisme sangat erat karena saling berhubungan dan setiap struktur itu memiliki fungsi masing-masing.

Sebagai contoh, dalam sebuah keluarga misalnya. Terdiri dari ayah, ibu dan anak. Ayah adalah pemimpin rumah tangga yang berfungsi atau bertugas mencari nafkah serta memberikan kehidupan yang layak, keamanan dan kenyamanan dalam keluarga. Ibu merupakan mitra ayah dalam menjalankan fungsi tersebut. Ibu sebagai pengontrol anak, memberikan pengajaran yang baik untuk anak. Sedangkan anak harusnya berbakti kepada orang tua dengan melakukan hal yang baik, tidak mengecewakan orang tua serta membahagiakan orang tua tentunya.

Dari contoh di atas sangata erat kaitan antara fungsioanlisme dengan strukturalisme, jika salah satu stuktur tidak berfungsi dengan baik, maka struktur yang lain juga akan terganggu.

Lebih dari itu fungsionalisme struktural menganggap bahwa segala sesuatu yang ada didalam masyarakat ada fungsinya masing-masing. Termasuk seperti kemiskinan, peperangan maupun kematian. Seperti apa yang dikatakan Herbert Ganz dalam Pip Jones, (2009:51) bahwa "kemiskinan fungsi tersendiri bagi orang kaya". Dan patut kita sadari bahwa kemiskinan mempunyai fungsi bagi orang kaya untuk menciptakan mekanisme dalam bekerja yang esensinya menimbulkan hubungan timbal balik antara orang kaya dengan orang miskin karena belum tentu orang kaya memiliki segala sesuatu yang ada pada orang miskin begitu juga sebaliknya misalkan kaya hati.

5. Kelemahan teori fungsionalisme

Beberapa kelemahan yang terdapat dalam teori fungsionalisme diantaranya adalah sebagai berikut:

a. Teori ini tidak bisa menentukan perubahan dalam artian hanya bisa digunakan untuk fungsi yaitu bagaimana kebudayaan itu dapat berjalan dengan baik.

b. Teori ini tidak bisa merespon secara utuh dalam kebudayaan yang kita respon karena ia hanya berfungsi secara umum.

\section{PENUTUP}

1. Kesimpulan

Dari pembahasan diatas dapat pemakalah tarik beberapa kesimpulan, yaitu: 
a. Fungsi kebudayaan, kemampuan suatu kebudayaan untuk memenuhi kebutuhankebutuhan individu anggotanya.

b. Fungsionalisme sebagai sistem integral, jika salah satu sistem terganggu maka keseimbangan suatu sistem akan terganggu .

c. Fungsionalisme dan strukturalisme sangat berkaitan, setiap struktur dalam msyarakat memiliki fungsi masing-masing.

2. Saran

Dalam pembuatan makalah ini masih banyak terdapat kekurangan. Oleh karena itu kritik dan saran yang membangun dari pembaca senantiasa pemakalah harapkan, yang nantinya dapat dijadikan sebagai titian usaha perbaikan lebih lanjut.

\section{DAFTAR PUSTAKA}

Baal, Van. 1988. Sejarah dan Pertumbuhan Teori Antropologi Budaya. Jakarta: PT Gramedia. Syam, Nur. 2006. Mazhab-Mazhab Antropologi. Yogyakarta: PT Lks Pelangi Aksara. Koentjaraningrat. 2007. Sejarah Teori Antropologi I. Jakarta: Universitas Indonesia. http://www.scribd.com/doc/23711839/teori-fungsional

Pip Jones. Alih Bahasa: Achmad Fedyani Saifuddin. 2009. Pengantar Teori-Teori Social Dari Teori Fungsionalime Hingga Post-Modernisme. Jakarta: Yayasan Pustaka Obor Indonesia. 